\title{
THE "PROBLEM" OF ASPECTS OF TEACHING AND LEARNING / TEACHING - LEARNING IN EUROPEAN UNION LAW
}

\author{
Anda Veronica Nedelcu-Ienei, $\mathbf{P h D}$ \\ "Vasile Goldis" West University of Arad \\ University of Timisoara
}

\begin{abstract}
Motto:
I imagine an education system that recognizes what learning is natural, You love learning is normal and as an authentic passionate learning means learning. A curriculum the school considers the questions more than the answers... Creativity more than reproducing information... More individuality than conformism... And excellence more than the standard achievements.
\end{abstract}

(Tom Peters)

\begin{abstract}
The paper addresses an important problem and the frequency of teaching and learning/teaching-learning in higher education/university student, generated by the incapacity to himself selectively information conveyed through alternative sources.

The theoretical approach of the course in European Union law from the dual perspective of the studies about the EU (from the perspective of Community law/EU of the European economy as well as from the perspective of the European administration, international relations and historical and cultural studies or interdisciplinary) require students to knowledge/concept related institutions entrusted with the exercise of prerogative powers in a State, who they studied/problems in previous years in fact, it is precisely this times is done or shall not become unwieldy.

And last but not least not be overlooked aspects of individual differences that influence the process of learning: the way of thinking and the preferences of both factors (teachers/students) on lifelong learning, which influences the effectiveness of the approaches in the process of instruction (or multiple types of intelligence entitled, the use of information and others).
\end{abstract}

Keywords: Community law, European economy, international relations, administration, external dimension of sovereignty, the sovereignty of the State, the binomial theorem integration-enlargement, democratization of European society, Europeanization of public space, diplomatic missions.

\section{INTRODUCTION}

We live in a society that develops into a very fast pace in which knowledge becomes obsolete ever more quickly, the information becomes accessible to more and more rapidly through computer networks, the need for lifelong learning, and teaching models based on the transmission and storage of knowledge students lose 
Nedelcu-Ienei, A.V. (2015)

The "problem" of aspects of teaching and learning / teaching - learning in European Union law

their functionality and acquire some knowledge exam and not only because they represent some intrinsic values as educational purposes.

Even though higher education institutions are recognized for their "ivory tower", history has shown us that even these from time to time "they shook" tower "in order to accommodate the new vision of the company.

As a doctor in public international law and Professor of law at the law school teaching disciplines: international public law, European Union law, diplomatic and consular Law and European law Ministry, and I deal with many obstacles/problems in my work teaching and learning or learning-teaching courses for students of different years of study.

I will refer to one of the subjects they teach to third-year students within the Faculty of Legal Sciences: European Union law.

Theoretical approaches to the European Union may be different; Obviously, I'll tackle dual studies from the perspective of the European Union concerned about from the perspective of legal sciences (Community law), and the (economy), but as well from the perspective of international relations, administrative (Management Board), which does not mean that I do not use with much success and studies from the perspective of cultural and historical significance, and not infrequently and the interdisciplinary.

In any nation, the right was considered the Foundation administering the social, economic and political. From the very definition of the law, it follows that every State shall bind the indispensable existence; the State and society and may confer the right of a flexible nature.

Note the fact that the right is an attribute of a State in respect of it, where as a result the right lies in a report of interdependence.

\section{TABLE of CONTENTS}

In the contemporary period, we may assert that right becomes the State's higher education system because legal standards are those that limit the power of a State to exercise.

We considered absolutely necessary to address the importance of social, economic and political relationship between the law and the State to ensure that students in this discipline that you teach, to understand the source and mechanism of European Union legislation, the approach of the space in which our country has wanted and managed to fall.

And in order to fully understand the complex phenomenon of binomial theoremenlargement, integration is essential for the existence of legal instruments complementary to both, as well as the economic one, because integration is mixed, i.e. legal and economic policy, at the same time. Therefore be entered in the equation and related issues: 
- A new political regime;

- A new legal order;

- A new economic-social model.

The study of European integration is a tribute to the way of understanding the European Union and therefore bringing context to questions like:

- How do we define the European Union?

- What is its nature?

- What is European integration?

- What it is and how it is performed?

- What is the ratio of European unification?

- What is the relationship with European society democratization or why not that of world society? and I got all sorts of answers from the understanding of the European Union as a mere international organization until the political system (more or less consolidated), to the idea that the European Union would actually be an entity sui-generis, or a Federation of independent States, answers that could not be substantiated due to lack of permits, which should have been learned from previous disciplines on some subjects, they were promoted through the examinations but they have learned through memorization and they have forgotten and others simply failed to pass these exams.

Once you have provided the perspective from which we look at this topic, the theory will be one specifying that requires first of all, the magazine and the classification of the most important principles, concepts and State-related institutions entrusted with the exercise of prerogative powers. Starting from this idea, we deemed it necessary and imperative to realize (together with students if possible!) incremental aspects with regard to the concept of the State, State power and legitimacy to the exercise of its sovereignty, the State form, form of Government, the concept of a legislative institution, its organization and functions.

We cannot study the relations existing between the State and the law without a dialogue, interaction with students and the understanding of some fundamental terms such as State, power state (sovereignty), types of elections, State, shape form of Government (separation of powers) and legitimacy, to see national differences from the face of the community; issues studied by students in previous years, the respective study year; this cannot be done since they have not been able to learn/able to understand the lack of affinity for the discipline, which led to the us rate oflexaminer examination of the constitutional law since I and/or of the General Theory of law and discipline the whole of the first year of study by making it impossible for the understanding of the concept of sovereignty, nationality, the separation of powers in a State, or State shape.

The legitimacy of power attract a democratic theory of sovereignty on which students have studied it, based on the principle of the sovereignty of the people and 
Nedelcu-Ienei, A.V. (2015)

The "problem" of aspects of teaching and learning / teaching - learning in European Union law

a theory based on the principle of national sovereignty, the students must know the fact that what is accepted and transposed at the constitutional level is given by popular sovereignty, or that is sometimes missing from the knowledge accumulated by some students, I think due to the non-motric element- the student's desire to learn.

Example: having studied the pattern of German sociologist Max Weber who believe that there are three types of legitimacy of power on whose behalf leaders can exert its dominance in general very few students or close to the place are not attracted by reading further and others exhibit a lack of interest and a weight of understanding concepts and their respective connections.

Example: according to renowned Tudor constitutionalist ^ , if absolute, the absolute power of the State with a single person, while nowadays, State power is "a system of organs competent to exercise the functions of Government: legislative, executive and judicial jurisdiction to issue about unilateral acts binding and which, each in their purview, to have recourse to force organized to ensure normal life in the pursuit of common". And here in Bible deal with lack of the role student to become an active manipulator.

Another issue I'm facing with is the size of the external of State sovereignty; I must say that, within the framework of international organizations, there may be talk of sovereignty, which is the preserve of the State, but I hit the same shortcoming of the student who has not promoted the subjects constitutional law and public international law (2nd year of study) in which a chapter is devoted to international organizations (discipline that also teach them myself).

Example: both within the United Nations (UN) and in the case of the European Union today may not be talking about sovereignty than a transfer of jurisdiction from the State super State.

The concept himself of contemporary international law sovereignty changed, sovereignty as a legal concept is absolutely incompatible with the phenomena being integration and the existence of international legal order and due to the lack of capacity by students to select what is necessary, I'm having difficulty in teaching and learning in class.

Another problem I'm facing is precisely the quality of students, because my courses and other specialists you right you are indicated as compulsory, but only bibliography some studying them, others do not have the ability to select what is necessary, while others do not read them, not interested (defending us rate).

Having the privilege to teach such students and discipline of international public law, in the second year of study, can better known ability of these students and the lack of interest of some for some disciplines, though most of them wish to pursue upon graduation diploma in European Union. 
Example: the institution of citizenship is addressed and the both disciplines (taught me): public international law where they learned as it represents the link between individual policy-legal and State and the Right of the European Union for European citizenship to be studied.

For the study of European citizenship be determined as key concepts:

- Citizenship;

- European citizenship;

- European identity;

- European democracy;

- Europeanization of public space;

- Construction of European citizenship.

The problem that I'm facing refers to passivity and lack of interest, perhaps motivated by lack of knowledge, the exchange of information. I encourage to seek together, after discussions and confrontations, the solution to the problem discussed anti-discrimination, also encouraging them to communicate openly, to listen and to respect the opinion of others students. Every time I expect constructive feedback for group/issue discussed anti-discrimination.

To all this add and knowledge acquired from other disciplines, studying important documents, referred to whenever I rate international and European legislation in this field, without which no one can understand neither the European Union nor the place and role of the European citizen and the European citizenship (Council of Europe -general rights and the European Union with its institutions-specific rights and as the institutions first and foremost to the European Court of human rights (ECHR) and the European Convention on human rights, namely the Charter of fundamental rights in the European Union.

Every time we propose students to formulate their own questions about the documents produced, they can have an own approach and vision of international law in this field.

By the Treaty of Maastricht, citizenship of the Union was created, i.e. the establishment of a policy and legal relationships between subjects of international law called the European Union and the individual citizen to enjoy rights and obligations: since then EU citizenship occupy a central place in the treaties.

Basically through creating this citizenship of the Union is in excess of the definitive economic barrier, creating both a Union policy, as well as a new legal institution, located in the service of the citizen, which allows for the exercise of the rights of citizens and out of the State.

Without knowledge of their movement into European space becomes a cumbersome, exposing them to diverse problem more or less enjoyable.

Another problem with which $\mathrm{I}$ am in the business of teaching and learning/teaching-learning occurs and the question regarding this character Paran 
citizens: citizenship of the Union is complementary or replacement therapy in relation to the national team? (according to article 20, part II of the TFEU)?; where results that some students had not studied the material library binding for each course indicated/topic, article 9 of the Treaty-part constitutional TEU and TFEU article 20 of part-operational and functional-they could not discover the fact that nationality does remove and do not replace national citizenship and at the same time the fact that the attribution of nationality by a EU country you exclusively the internal rules of the Member State concerned, and attribution or withdrawal of nationality the Union citizen depends on each status in relation to the EU country in which he lives or from which it originates, and from other discipline-international public law, must know Additionally, if they are located outside the borders of the State, namely the EU, enjoy rights guaranteed through the nationality of both disciplines for the protection of diplomatic missions of any EU state that has such a diplomatic or consular mission in the State it was in whether the State of nationality has a diplomatic mission or not.

The problem I'm facing with in this case consists in the lack of active learning based on research, exploration of students, although most have access to the mass media and the internet (ICT).

Another problem I'm facing in my work at the Department, lies in the lack of logic students to discern the difference between the rights laid down in the Charter which are binding on all Member States and the specific rights set out by the Charter cannot be contrary to the General ones set by the Lisbon Treaty and nor can they prevent the exercise of those laid down in the Treaty, but not provided for in the Charter, this fact is evident from the responses to the evaluation tests.

At the same time through the Lisbon Treaty the European Union legal personality, i.e. is fully subject of international law, which allows it to open 160 own embassies which may represent the citizens of the Union in third countries, as well as accredited diplomats of EU countries in these embassies, who did not want to have their own missions, but only to be represented among themselves bilateral and in order to be able to support citizens in their respective countries.

\section{CONCLUSIONS}

In this example the result once the problems that I'm facing in the overall activity of teaching and learning/learning-teaching of the course of law of the European Union: the fact that some students missing them the ability to select and store concepts needed to be General/should operate in each discipline and the interdisciplinary of the disciplines (lack of logic and of the link between 
"Vasile Goldiș" Western University of Arad

Nedelcu-Ienei, A.V. (2015)

The "problem" of aspects of teaching and learning / teaching - learning in European Union law

disciplines) and/or can exist and lack of interest for faculty followed they were interested in, just graduating without a practice, for a "bachelor's degree that sounds good-law graduate"; the low level of knowledge reflected in the evaluation (minimum, medium grades below the level of a student) due to decreased luggage coming from pre-university education and last but not least a lack of motivation.

In Romanian education, both school programs/curriculum are made of such a nature as not to provide to students the opportunity to build some pillars of the link to be able to acquire the necessary knowledge in higher education/University, as well as the fact that they do not possess the ability to select what is appropriate.

Material conditions are those which do not allow families to support dependent children as the student, the teacher cannot alone, with all the intention of counseling to address both valence: parent and teacher.

In addition to high schools and economic administrative law, there is no curriculum for knowledge/learning some elementary notions of law because it requires that prospective students are able / capable to participate in the marathon for learning law.

The teacher uses a specific language in question, and discipline students must acquire this legal language; the teacher facilitates the acquiring of knowledge by indicating the appropriate bibliographical material and binding each of the study subjects from all years of college education, through courses, basic law, treated casuistic/collections, cuts projections of documentaries by specialty consultations, explanations, scientific circles, essays on the topic of your choice, imposed or tests, questionnaires, however if there are studied and learned the student cannot form that teacher-student dialogue but only a monologue.

Conclude with the conviction/consider that's why is called student, to study individual courses and each course's introduction received/discipline made available by the teacher, because it assumes that the student is able to participate in this marathon for learning right and without holding a handbag and specialized general knowledge cannot make a modern education and student-centered if not studying/practicing the course, cannot be expressed in the subjects in question, nor can make relations between the disciplines to be able to juggle the concepts studied and learned previously (I, II, III).

That is why I consider that the competence of the competition without admissions offers each student scholarships, further able to not promote exams from previous years and the possibility of its inclusion in subsequent years, lead to loopholes for those students and last but not least the lack of a genuine interest in the shape of a piece of luggage of knowledge by studying all the bibliographic material made available by the teacher in class, or learn to 
"Vasile Goldiș" Western University of Arad

make presentations to colleagues, to learn by doing reports and projects, to study and to learn through discovery.

Although the teacher do with her advice but the student in its turn, must blame why not prepared with elucidated/why not understood/why he wanted to tell the author that has followed it and how they understand them, and to his replica to understand in the end.

At the same time the teacher has to make scientific circles in the subjects taught in order for students to be able to debate the most significant cases.

The fact that I do not read legal documents may not specialize and produce specialty papers/accomplish for homework completed, so don't make them or copies of reports on the internet.

Besides the negative aspects for higher education/academic, presented above, I want to point out the fact that I find totally unproductive and useless academic society, and finally the fact that if students fail to hold the exams from previous years (I-III, the respective courses of basic concepts for the meaning the next year of study) is missing the glue between disciplines, for example: constitutional law General law theory, civil law-People, roman law, public international law...

And in conclusion to all aspects/problems that I'm facing both myself and my other colleagues, I considered that it is necessary to point out that we must not neglect the aspects of individual differences that influence learning process, i.e. the way in which we think and students and our students and preferences with regard to influencing the effectiveness of different learning approaches in the instructive educative, i.e. the existence of:

- Multiple intelligence types who are entitled to the best;

- How you prefer to receive and use information and

- How you prefer to act in a learning situation,

What generally is not taken into consideration is lost sight of.

And however one very important thing is the quality of the student, provided that this study, quality of converted into his ability to be competent and to be able to work in the upcoming noble profession, jurist and famous words of Galileo Galilei:

"You cannot teach a man anything. You can only help it to discover that thing inside him".

Bibliography

1. Cain, I. (2002), Training systems, alternative and complementary. Structures, styles and strategies. Publishing House, Bucharest, Aramis.

2. Hugon, C. (2002), Pedagogy, Polirom Publishing House, Iasi. 


\section{JOURNAL OF LEGAL STUDIES}

"Vasile Goldiș" Western University of Arad

Nedelcu-Ienei, A.V. (2015)

The "problem" of aspects of teaching and learning / teaching - learning in European Union law

3. Barbulescu, I. G., (2015), New Europe. Identity and European model (vol. I), Editura Polirom, Iasi.

4. Zaharia, S.E.; Marinas, I. (coord.) (2005), Partners for excellence in the Europe of knowledge. The Romanian University in the context of "Bologna" and "Lisbon" (vol. I). National Agency for Universities Partnership with the economic and Social Environment.

5. Nedelcu - Ienei, A.V.; (2011), European Union law, the publishing house Cordially Lex, Cluj-Napoca.

6. Singer, M.; Chris, L. (2006), Qvo vadis, Academy? Benchmarks for an in-depth reform in higher education, Bucharest, Editura Sigma.

7. Ungureanu D., (1999), Education and curriculum, Timisoara, Editura Euro Stampa.

8. Vintanu, N. (2001), University Education, Bucharest, Editura Aramis.

9. University of Glasgow (2004), Student-Centred Learning, Web page http://www.gla.ac.uk/otherdepts/TLS/Project/Reports; Glasgow University Student-centered Education. 